REVIEW ARTICLE

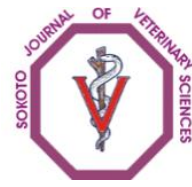

Sokoto Journal of Veterinary Sciences

(P-ISSN 1595-093X/ E-ISSN 2315-6201)

Hassan \& Salih/Sokoto Journal of Veterinary Sciences (2013) 11(2): 1-9.

http://dx.doi.org/10.4314/sokjvs.v11i2.1

\title{
An overview of factors responsible for geographic distribution pattern of ixodid ticks in the Sudan
}

\author{
SM Hassan \& DA Salih* \\ Veterinary Research Institute, University of Khartoum, Sudan
}

\begin{abstract}
*Correspondence: Tel.: 00249183380015, E-mail: diaeldin2000@hotmail.com
Abstract

Tick fauna in the Sudan comprises over 70 species prevalent in diverse ecological zones. Among these are the most economically important ticks in Africa, namely Rhipicephalus appendiculatus, Hyalomma anatolicum, Amblyomma variegatum, Amblyomma lepidum, Rhipicephalus (Boophilus) decoloratus and Rhipicephalus (Boophilus) annulatus. Several factors determine the dynamic changes of tick distribution in the Sudan. These are animal movement either for trade, nomadism, or migration due to civil unrest etc., habitat modification such as deforestation, largescale mechanized cultivation and urbanization; drought and desertification, and global climate change. The accelerated change in tick distribution results in outbreaks of several tick-borne diseases. Examples of these are East Coast fever, tropical theileriosis, malignant ovine theileriosis, heartwater and babesiosis by Babesia bovis. Emergence of these diseases in districts believed to be free is alarming and has adverse effects in the process of animal resources development. This communication discusses distribution patterns of the economically important livestock ticks in the Sudan and identifies new zones where ticks have established and the possible factors determining such distribution.
\end{abstract}

Keywords: Distribution, Factors, Livestock, Sudan, Ticks.

Received: 23-07-2013

Accepted: 04-10-2013

\section{Introduction}

The Sudan occupies an area of one million square miles, extending from $4-22^{\circ} \mathrm{N}$ of latitude and $22-$ $38^{\circ} \mathrm{E}$ of longitude, bordering on nine African countries namely Egypt, Libya, Chad, Central African Republic, Democratic Republic of Congo, Uganda, Kenya, Ethiopia and Eretria. It consists on the northsouth direction of desert, semi-desert and Savannah of unique floral and faunal set up with five identified ecological zones of rainfall. Animal resources contribution in the gross domestic product (GDP) is estimated at about $20 \%$. Livestock population accounts for 30 million cattle, 37 million sheep, 33 million goats and 3 million camels. About $39 \%$ of these are kept in the western Sudan, $27 \%$ in the southern, $24 \%$ in the central and $10 \%$ in the eastern and northern Sudan. About $80 \%$ of livestock population is owned by the traditional sector, namely nomads.
Tick fauna in the country comprises of over 70 species prevalent in diverse ecological zones. Among these are the most economically important ticks in Africa, namely Rhipicephalus appendiculatus, Hyalomma anatolicum, Amblyomma variegatum, $A$. lepidum, Rhipicephalus (Boophilus) decoloratus and $R$. (B) annulatus. These tick species are of veterinary importance in the Sudan. $R$. appendiculatus is the main vector of East Coast fever which is responsible for high mortalities of cattle in Southern Sudan (FAO, 1983). Similarly, H. anatolicum, the vector of tropical theileriosis and malignant ovine theileriosis which are considered the main obstacles of animal production improvement in the Sudan (Latif \& Shawgi, 1982; Imam, 1995). An accurate map of distribution of these ticks countrywide is still lacking. Hoogstraal (1956) identified ticks of the Sudan but did not draw a distribution map with the exception of Equatoria Province. Current knowledge on 
tick distribution in the Sudan is based only on fragmentary pieces of work carried out to date. Nevertheless, several factors determine the dynamic changes of tick distribution in the Sudan. These are animal movement either for trade, nomadism, or migration due to civil unrest etc., habitat modification such as deforestation, large-scale mechanized cultivation and urbanization, drought and desertification, and global climate change.

The accelerated change in tick distribution results in outbreaks of several tick-borne diseases. Examples of these are East Coast fever, tropical theileriosis, malignant ovine theileriosis, heartwater and babesiosis by Babesia bovis. Emergence of these diseases in districts believed to be free is alarming and has adverse effects in the process of animal resources development. This paper discusses distribution patterns of the important livestock ticks in the Sudan and identifies new zones where ticks have established and the possible factors determining such distribution.

\section{Possible factors influencing tick distribution in the Sudan \\ Animal movement}

Nomadism: Animal movement from an ecological zone to another is widely considered as means of introduction of ticks into new ecosystems (Cumming, 1999). In the Sudan, about $80 \%$ of livestock are owned by the traditional sector, mostly nomads. Cattle routes (Baggara type) in South Darfur are north-south direction. The tribes that follow these routes are Ta'aisha, Fellata, Habbaniya, Benihalpa, and Rizeiqat (Abdel Rahman, 2002). They reach beyond latitude $8^{\circ} \mathrm{N}$ in the south and $14^{\circ} \mathrm{N}$ in the north. Ticks that are expected to have changed their distribution or emerged in new zones are $A$. variegatum, A. lepidum, $R$. (B) annulatus and $R$. pretextatus (Karrar et al., 1963, Osman, 1978, Osman et al., 1982, FAO, 1983, Latif \& Hassan, 1997, Walker et al., 2003, El Imam, 2003, Salih et al., 2004, Abdalla \& Hassan, 2010). In the neighbouring province of Kordofan, the tribes such as Misairiya, Hawazma and Awlad Humaid also follow certain north-south migration routes. Cattle of the latter tribe are expected to mix with cattle along the White Nile. This is significant for spread of $H$. anatolicum and $A$. lepidum to the western parts of the country. In the central Sudan, between the White Nile and Blue Nile, cattle routes of Rufa'a tribe, north-south direction, are also important in the advance of $H$. anatolicum to the south direction.
Migration: In the Republic of southern Sudan, migration of cattle of Dinka and Neur is expected to disseminate the newly introduced tick i.e. $R$. appendiculatus that is believed to be confined in Eastern Equatoria (Jongejan et al., 1987). However, Zessin \& Baumann (1982) detected antibodies against Theileria parva among cattle in Bahr el Ghazal Province.

\section{Habitat modification}

Change in vegetation cover such as deforestation, establishment of large scale agriculture schemes, drought and desertification and global climate change affects macro and microclimates, habitats of ticks and hence their existence or nonexistence.

Deforestation: Approximately 25 million acres of tropical rain forests are lost each year. The destruction of this biomass accounts for $20 \%$ of the anthropogenic $\mathrm{CO}_{2}$ emitted into the atmosphere every year (Helikson \& Jones, 2002). Sudan forests have drastically decreased during the last decades. About 1.1 million acres were deforested annually during 1980 - 1990. FAO (1997) reported that forest cover in the Sudan is estimated to be $12 \%$ of the total area of the country while it was $18 \%$ during 1980 's and 36\% in 1950's. Land utilization in Sudan as at 1997 is shown in Table 1. Mohamed (2000) reported that steady deforestation that has occurred over the previous twenty years under the combined effects of agricultural encroachment, fuel wood cutting and overgrazing, has reduced forest area by $20 \%$. Deforestation in the Sudan ranges between 210,000 and 420,000 hectares within an annual average of 365,000 hectares (Mohamed, 2000).

Large-scale mechanized cultivation: Mechanized farming schemes have taken up to 4 million hectares of forest lands, some of which after 3 to 4 years of continuous sorghum cropping have been abandoned and left lying idle. Distribution of economically important ticks is expected to have been affected by manipulation of the vegetation cover. This change remains to be elucidated.

Drought and desertification: Drought and desertification have a direct and indirect effect on tick survival in the affected regions. Unfed ticks have the ability to survive for several months but succumb to high temperature and low humidities. In the Sudan, El Ghali and Hassan (2010) released ticks under direct sunlight in bare land and found that they survived for only one week while in the shade they survived for several months. Similar results had 
Table 1: Land utilization in the Sudan in 1997.

\begin{tabular}{ll}
\hline Land utilization & Area* \\
\hline Forest and wood-land & $134.67(22.6 \%)$ \\
Productive forest & $52.18(8.78 \%)$ \\
Shrub and desert Shrub & $103.14(17.34 \%)$ \\
Gazetted forests & $18.41(3.11 \%)$ \\
Wildlife reserves & $42.24(7.12 \%)$ \\
Swamps and water surfaces & $3.44(0.59 \%)$ \\
Arable cropped land & $40.26(6.77 \%)$ \\
Desert and urban & $200.81(33.5 \%)$ \\
\hline
\end{tabular}

* Area in million acres.

Source: Mohamed (2000).

been obtained by Mohamed et al. (2005). A prolonged drought occurred almost all over the Sudan for a succession of years (1981-1985). Karrar (1987) reported that some parts of East and West of the country had already been in the grip of moderate to severe desertification for more than two decades. The author added that due to drought and desertification, crop cultivation failed, grazing lands became barren and water wells dried up. The worst scenes were in Northern Kordofan and Red Sea Provinces. During the onset of drought prolonged overgrazing, overcultivation and deforestation aggravated the problem. Total area affected by drought and desertification was estimated at 1.5 million $\mathrm{km}^{2}$ in the east and west of the country while millions of livestock perished. Surveys in western Sudan in 1975 revealed that desert had advanced 90 to $100 \mathrm{~km}$ in a 17-year period (Bayoumi, 1984). He, also, reported that the forest area decreased from 584,362 km in 1968 to $559,015 \mathrm{~km}^{2}$ in a 13 -year period. These factors have tremendous impact on redistribution of the ticks. Ticks which are expected to have been affected by desertification in Kordofan and Darfur include Hyalomma detritum, $H$. anatolicum, A. lepidum and A. variegatum as discussed below.

Wildlife species are considered as alternative feeding hosts of ticks as they act as important means of dispersion of ticks. A variety of wildlife species occupy different vegetation zones that range from desert and arid lands at extreme north of the Sudan to relics of tropical rain forests in the South. These species are slowly vanishing due to desertification and relevant habitat deterioration (Bayoumi, 1984). National Parks in the country are Dinder National Park $\left(6,400 \mathrm{~km}^{2}\right)$, Southern National Park $(16,850$ $\left.\mathrm{km}^{2}\right)$, Nimuli National Park $\left(260 \mathrm{~km}^{2}\right)$ and Radom
National Park $\left(12,500 \mathrm{~km}^{2}\right)$. Wildlife reserves are expected to be 42.24 million acres (Table 1 ). In the last three decades, several factors assisted in the sharp decrease of wildlife in the Sudan. These include drought, desertification, human activities such as drastic increase in mechanized agriculture at the expenses of natural range land, unauthorized hunting of wildlife and urbanization activities (Nimir, 2001). Several species of wildlife, for instance, have disappeared in Eastern Sudan, Northern Kordofan and Darfur. In Dindir National Park, only 3\% of animals used to inhabit in the seventies are currently remaining (Abdel Hamid, 1999). In Radom National Park, several species of wildlife have suddenly decreased particularly elephant, giraffe, buffalo, eland, lion, tiger, ostrich (Nimir, 2001). Ticks, which particularly feed on wildlife have either changed their geographic distribution or disappeared from these parks. Examples of these ticks include Amblyomma cohaerens, Amblyomma rhinocerotis, Dermacentor circumguttatus and Hyalomma bouyi.

Global climate change: The concern over global climatic change has arisen due to the fact that the atmospheric quantities of carbon dioxide $\left(\mathrm{CO}_{2}\right)$, methane $\left(\mathrm{CH}_{4}\right)$, nitrous oxide $\left(\mathrm{N}_{2} \mathrm{O}\right)$ and chlorofluorocarbons (CFCs) are rapidly increasing. CFCs have heat holding capacities 15,000 times greater than $\mathrm{CO}_{2}$. An increased quantity of greenhouse gases in the troposphere decreases the chances of heat energy escaping the troposphere. The following changes are likely to occur; an average warming of the Earth by $3-8$ degrees $F$, outbreaks of floods or drought, proliferation of agricultural pests and an increased rate of species extinction (Helikson \& Jones, 2002). The impact of global warming on distribution of ticks and emergence of 
tick-borne diseases in the Sudan remains to be investigated.

Ambient temperatures and relative humidities are critical factors determining longevity of ticks decreasing with high temperatures and low humidities. In Australia, $10 \%$ of ticks released in pasture during summer survived for 4 weeks while the comparative value for winter was 11 weeks (Utech et al., 1983). Hassan (1997) found that survival of ticks under direct sunlight was significantly shorter compared to those in the shade. Long and thick vegetation cover provides shade and optimum humidity in microhabitats of ticks thereby enhancing their survival. Ixodes spp. die quickly of desiccation when exposed to humidity below their critical equilibrium humidity (Stafford III, 1994). A relative humidity range of $60-70 \%$ was critical for Rhipicephalus appendiculatus below which survival of eggs and larvae was limited (Punyua, 1985). Hassan (1997) found that survival of Amblyomma variegatum and $R$. appendiculatus during the rainy season was significantly higher compared with dry season.

Change in tick distribution patterns in the Sudan Amblyomma lepidum: It is classified as a dry region tick species prevalent in central and east African countries. In the Sudan, it is abundant in eastern parts of the country (Walker and Olwage, 1987; Karrar et al., 1963). A significant change has occurred to this tick species due to factors such as development of large agricultural schemes, deforestation and movement of animals for search of pasture (Fig. 1). In eastern Sudan, El Amin et al. (1986) observed that there was a shift to the south in areas where this tick had not been reported. This was confirmed by Mohamed et al. (2005) who found that $A$. lepidum has become abundant in Edamazin Town $\left(12^{\circ} \mathrm{N}, 34^{\circ} 25^{\prime} \mathrm{E}\right)$. This species has made another shift on the west direction being abundant along the White Nile in Kosti $\left(13^{\circ} \mathrm{N}, 32^{\circ} 35^{\prime} \mathrm{E}\right)$, (EI Imam, 2003). He found that this species outnumbered other ticks, a fact that confirms that this species is moving to the west direction (Fig. 1). It is not clear whether $A$. lepidum is replacing $A$. variegatum or not a fact which leaves the field open for further studies.

Karrar et al. (1963) argued that until early 1960's it was believed that $A$. lepidum did not exist to the west of the Nile in Kordofan and Darfur. Osman (1978) in his collections from many localities in Darfur found only males of $A$. lepidum from three localities. However, later, Osman et al. (1982) reported that $A$. lepidum which had not been common in west of the Nile according to Hoogstraal (1956) became extensively distributed in the semi arid and savannah of Kordofan and Darfur. Sowar (2002) reported that $A$. lepidum was the most dominant tick species in Southern Kordofan. These reports indicate that $A$. lepidum is extending its distribution to the western parts of the country. Recently, Abdalla \& Hassan (2010) found this tick species abundant all over South Darfour. It is alarming that $A$. lepidum which used to be confined in eastern parts of the African continent (Walker \& Olwage, 1987) may reach West African countries in the near future. This would aggravate and complicate the situation of heartwater and dermatophilosis in West African countries.

Amblyomma variegatum: This tick is also spreading to new ecosystems (Fig. 1). Hoogstraal (1956) indicated that the northern limit of $A$. variegatum was $12^{\circ} \mathrm{N}$. He found this tick species from Edamazien Town $\left(12^{\circ} \mathrm{N}, 34^{\circ} 25^{\prime} \mathrm{E}\right)$. Later, Jongejan et al. (1987) and Mohamed et al. (2005) did not encounter this tick species in Edamazien. Disappearance of $A$. variegatum could be attributed to the fact that this part of the country is where large scale mechanized agriculture schemes are established. It is, also, an area where deforestation is intensively practiced. These two important factors must have changed macro and microclimatic habitats of this tick species. In Kosti Town $\left(13^{\circ} \mathrm{N}\right.$, $\left.32^{\circ} 35^{\prime} \mathrm{E}\right), A$. variegatum has crossed the northern limit defined by Hoogstraal (1956) as reported for the first time by El Imam (2003). It was also reported from El Obied Town $\left(13^{\circ} \mathrm{N}, 30^{\circ} \mathrm{E}\right)$ (Salih et al., 2004). Sowar (2002) observed in Dilling Town $\left(12^{\circ} \mathrm{N}\right.$, $28^{\circ} 75^{\prime}$ ) that $A$. variegatum disappears from animals during the dry season from December to April while A. lepidum is prevalent throughout the year. Animal movement is responsible for $A$. variegatum to cross the northern limit set by Hoogstraal (1956), especially in Darfur where it has established in Nyala area (Abdalla \& Hassan, 2010). However, capability of $A$. variegatum to establish and survive in dry hot area of Elobied and Nyala remains to be investigated. 


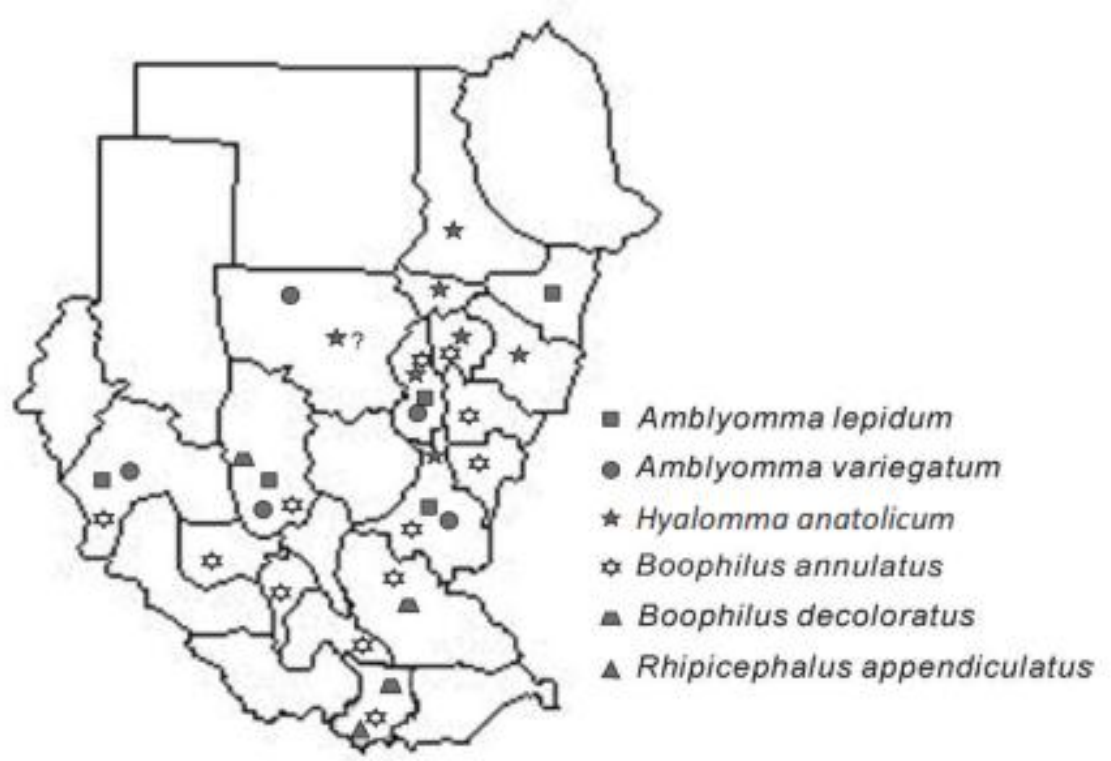

Figure 1: Geographical distribution of important ixodid ticks in Sudan

Hyalomma anatolicum: It is a xerophilic species thriving in semi-desert conditions in Northern Sudan (Fig.1). Jongejan et al. (1987) considered latitude $14^{\circ} \mathrm{N}$ to be its southern limit. It is spreading southwards in the Central Sudan. In the early 1980s, this tick species was not reported at Um Benain $\left(13^{\circ} \mathrm{N}, 34^{\circ} \mathrm{E}\right)$ (FAO, 1983) along the White Nile. Twenty years later, this species established in this locality (Salih et al., 2004). It has also extended its distribution along the White Nile to Kosti $\left(13^{\circ} \mathrm{N}\right.$, $32^{\circ} 35^{\prime} \mathrm{E}$ ) according to El Imam (2003) who found this species and $H$. excavatum for the first time in this ecosystem. However, he did not find these two tick species only $60 \mathrm{~km}$ and beyond to west of the Nile (Fig. 1). He attributed this absence to the husbandry regime where these tick species are only able to propagate inside cattle pens and do not infest cattle kept under outgrazing or nomadic systems. Animal movement and macroclimate change due deforestation and large-scale mechanized agriculture schemes could be responsible for movement of $\mathrm{H}$. anatolicum on the south direction although it does not inhabit high humid zones. This tick species has not been recorded in western parts of the country. In Nuba Mountains, western Sudan, Osman et al., (1982) among several Hyalomma species did not encounter $H$. anatolicum. Similarly, Sowar (2002) did not find this species in Dilling $\left(12^{\circ} \mathrm{N}, 28^{\circ} 75^{\prime}\right.$, about $100 \mathrm{Km}$ south of El Obied). In an ad hoc tick collection (Salih et al., 2004) did not encounter this species in $\mathrm{El}$ Obied $\left(13^{\circ} \mathrm{N}, 30^{\circ} \mathrm{E}\right)$,
Nyala $\left(12^{\circ} \mathrm{N}, 24^{\circ} 50^{\prime} \mathrm{E}\right)$, El Ginaina $\left(13^{\circ} 50^{\prime} \mathrm{N}, 22^{\circ} 30^{\prime} \mathrm{E}\right)$, nor El Fashir $\left(13^{\circ} 70^{\prime} \mathrm{N}, 24^{\circ} 45^{\circ} \mathrm{E}\right)$. However, unconfirmed reports indicate that this species has established in El Obied. This is substantiated by outbreaks of clinical theileriosis among exotic cattle and by high seroprevalence of $T$. annulata antibodies by ELISA conducted by Salih (2003). Animal movement along the White Nile could be responsible for $H$. anatolicum invading El Obied. In a recent tick collection from Northern Kordofan (Mohammed-Ahmed, 2011) H. anatolicum was not recorded. Recently, Abdalla \& Hassan (2010) identified a considerable number of $H$. anatolicum in Nyala (Fig. 1). Earlier Osman (1978) had collected only one male of $H$. anatolicum in Darfur from a donkey on a single occasion. This confirms that this tick species has established in Nyala, but has not yet spread to other localities of Darfour. Introduction of this species into Darfur was due to the recent introduction of Friesian cattle and their crosses from $H$. anatolicum infested area such as Khartoum and Central Sudan into South Darfur region. Introduction of $H$. anatolicum that could be infected with Theileria annulata into a non-tropical theileriosis endamic area such as South Darfur is alarming. Likewise, A. lepidum, $H$. anatolicum is steadily spreading from its ever known distribution zone of Eastern and Central Sudan (Jongejan et al., 1987) to western parts of the country. It will not be surprising for this economically important tick species to reach in the near future to the far West African countries 
carried by animals that cross the international borders to Chad, Niger and Nigeria.

Rhipicephalus (Boophilus) annulatus: It is considered a tick of humid area, was recorded in southern Sudan by Hoogstraal (1956) who pointed out that $R$. (B) annulatus had been reported from West Africa, Central Africa and certain parts of southern Sudan. It is now spreading to the northwards to much drier zones (Fig. 1). This is most likely due to continuous animal movement. FAO (1983) recorded this tick species as far north as Wad Madani $\left(14^{\circ} .25^{\prime} \mathrm{N}, 32^{\circ}\right.$ $\left.75^{\prime} \mathrm{E}\right)$ being abundant along the Blue Nile from Sennar $\left(13^{\circ} 50^{\prime} \mathrm{N}, 32^{\circ} 75^{\prime} \mathrm{E}\right)$ to Edamazin. It is difficult to explain why this tick of high humidity is able to survive in the drier ecological zones of Central Sudan. Along the White Nile, El Imam (2003) encountered this species in Kosti. Osman (1978) reported $R$. (B) annulatus in Southern Darfur for the first time. Later, Osman et al. (1982) found this species in several locations in Southern Kordofan being prevalent throughout the year. Sowar (2002) observed in Kordofan that $R$. (B) annulatus has reached a stage where it is able to outnumber $R$. (B) decoloratus. Abdalla \& Hassan (2010) confirmed that $R$. (B) annulatus has established in all localities of South Darfur (Fig. 1). Since during the dry season (November to April) cattle from Darfur region enter Bahr El Ghazal Province where this tick species is abundant (Zessin \& Baumann, 1982) they must be the source of introduction of this species into Darfur during the wet season (May to October). The possibility that $R$. (B) annulatus is replacing the coexisting $R$. (B) decoloratus is open for future studies.

It is noteworthy that the west African tick Rhipicephalus (Boophilus) geigyi has been collected from Southern Sudan, near Bor Town $\left(6^{\circ} 10^{\prime} \mathrm{N}, 30^{\circ}\right.$ 75') (Jongejan et al., 1987). This may not be surprising because this tick species had been reported from two districts in Uganda near the borders with the Sudan (Matthysse \& Colbo, 1987). However, Jongejan et al. (1987) argued that there have been various intrusions of West African tick fauna into the Sudan and re-examination of Rhipicephalus (Boophilus) collections may reveal more $R$. (B) geigyi. Nevertheless, the consequences of introduction of this new tick species in relation to tick-borne diseases have to be seriously considered. On the other hand, although $R$. (B) geigyi was reported in Central Republic of Africa (Walker et al., 2003), but it was not found in the survey conducted by Abdalla \& Hassan (2010). It is difficult to explain its absence in this region despite the fact that animals cross the borders to and from Chad in search of water and pasture. Similarly, these authors did not find Hyalomma detritum although Hoogstraal (1956) reported this species from Darfur area. Osman (1978), also, had not found this tick species in the same area. Probably, it has disappeared due to some climatic changes. On the other hand, prevalence of the West African tick species $R$. muhsamae in relatively large numbers in collection of Abdalla \& Hassan (2010) from Darfur is an indication that it is spreading in the eastern direction most probably through animal movement.

Rhipicephalus appendiculatus: In the neighbouring country, Republic of South Sudan, Rhipicephalus appendiculatus was first reported in Kajo Kaji near Ugandan borders (Hoogstraal, 1956). In late 1970s with the influx of Ugandan refugees owned cattle, this tick species was introduced into the Sudan and established in eastern Equatoia (Morzaria et al., 1981). In 1986, the Mundari herdsmen were forced to move their cattle from Terekaka $(60 \mathrm{Km}$ north of Juba) to Juba Town due to insecurity caused by the civil war (Fig. 1). On their return, ECF and $R$. appendiculatus were introduced in Terekaka (Julla, 2003). There is fear of spread of this species to extend its advance further north to Bor and the swampy area of Jongelei or to intrude Bahr El Ghazal Province which is free from $R$. appendiculatus (Zessin and Baumann, 1982). This tick species has not been identified among ticks collected from cattle in Makakal ecosystem in a cross sectional survey (Elfagiri \& Hassan, 2010, unpublished data). It is to be investigated whether $R$. appendiculatus is found in southern Sudan in foci and will be spontaneously eliminated and has permanently established and has spreading in all directions. The complications arise from the fact that CLIMAX shows that southern Sudan is not a suitable ecosystem for survival of $R$. appendiculatus (Latif \& Hassan, 1997). On the other hand, the impact of the civil war and insecurity must have forced herdsmen to change their traditional routes, grazing areas, time of grazing, or to keep their animals in new localities where they have never been before. The impact of such change in husbandry on distribution of ticks and emergence of tick-borne diseases should be determined.

In conclusion the accelerated change in tick distribution results in outbreaks of tick-borne diseases in non-endemic areas. Examples of these are East Coast fever in Southern Sudan (Salih et al., 2007), tropical theileriosis in Western Sudan (Abdalla 
\& Hassan, 2010), malignant ovine theileriosis in Khartoum State (Tageldin et al., 1992), heartwater in Eastern Sudan (Abdel Rahman et al., 2003) and babesiosis in White Nile State (Abdel Rahman, 2013). Emergence of these diseases in districts believed to be free is alarming and has adverse effects on the process of animal resources development. The areas at risk of East Coast fever in Southern Sudan are Unity State, Lakes State and Bahr elghazal region whereas most of the southern parts of Central Sudan are at risk of tropical theileriosis and malignant ovine

\section{References}

Abdalla MM \& Hassan SM (2010). Current status of distribution and population dynamics of ticks (Acari: Ixodidae) infesting cattle in South Darfur State, Sudan. University of Khartoum Journal of Veterinary Science and Animal Production, 1(2): 76-97.

Abdel Hamid SM (1999). Wildlife in the Sudan. In: A symposium on: Strategy and National Workplan for Biodiversity. (In Arabic). Pp 21-37.

Abdel Rahman AH (2002). Studies on the epidemiology of bovine trypanosomosis in the Sudan. PhD thesis, Department of Preventive Medicine, Faculty of Veterinary Medicine, University of Khartoum, Pp 195.

Abdel Rahman, AA (2013). Survey of Babesia bigemina in White Nile State, Sudan. MVSc thesis, Veterinary Research Institute, Animal Resource Council, Sudan Academy of Sciences, Pp 113.

Abdel Rahman MB Abdel Rahim Al El Hussein AM Hamid ME El Eragi AM Zakia A, Bakhiet MA Hind EA El Gadal A \& Jongejan F (2003). Sero-surveillance of cowdriosis (heartwater) in sheep in Eastern Sudan using MAP1-B ELISA. Sudan Journal of Veterinary Science and Animal Husbandry, 42(1): 167-175.

Bayoumi AA (1984). Renewable natural resources management and desertification in the Sudan. At-Tasahhur, 2(1):1- 6.

Cumming GS (1999). Host distributions do not limit the species ranges of most African ticks (Acari: Ixodida). Bulletin of Entomological Research, 89(4): 303-327.

El Ghali A \& Hassan SM (2010). Drop-off rhythms and survival periods of Hyalomma dromedarii (Acari: Ixodidae) fed on camels theileriosis. There is an urgent need to embark upon drawing a map of geographic distribution of ticks countrywide and to lay a long-term plan for a regular periodic monitoring and updating information. These studies should include prevalence and abundance of ticks, seasonal population dynamics, emergence of tick-borne diseases in non-endemic areas, replacement of a tick species to another coexisting one. Such project requires an interdisciplinary cooperation among tick ecologists and taxonomists, agriculturists, social scientists, and climatologists.

(Camelus dromedarius) in the Sudan. Veterinary Parasitology, 170(4): 302-306.

El Imam A H (2003). Ecological studies on ticks infesting cattle Kosti, Sudan. Sudan Journal of Veterinary Science and Animal Husbandry, 42(1): 62-71.

El Amin MA Mustafa BE \& Osman OM (1986). Observations on heartwater disease in Eastern region of the Sudan. Sudan Journal of Veterinary Research, 7(1): 23-31.

FAO (1983). Tick and Tick-borne Diseases control. AG:GCP/SUD/024/DEN. Food and Agriculture Organization, Rome, Pp 24.

FAO (1997). State of the World Forests. Food and Agriculture Organization, Rome, Pp 54.

Hassan SM (1997). Ecological studies on Rhipicephalus appendiculatus and Amblyomma variegatum (Acari: Ixodidae): Drop-off rhythms, development, survival and seasonal population dynamics. PhD thesis. Department of parasitology, Faculty of Veterinary Medicine, Kenyatta University, Pp 245.

Helikson H J \& Jones PH (2002). Global Climatic Change Primer. University of Florida, Cooperative Extension Service, Institute of Food and Agriculture Sciences, Pp 124.

Hoogstraal H (1956). African Ixodoidea. 1. Ticks of the Sudan (with special reference to Equatoria Province and with preliminary reviews of the genera Boophilus, Margaropus, and Hyalomma). Research Report NM005 050.29.07, US Naval Medical Research Unit No. 3. Pp 1101.

Jongejan F Zivkovic D Pegram RG Tatchell RJ Fison T Latif AA \& Paine G (1987). Ticks (Acari: Ixodidae) of the Blue and White Nile ecosystems in the Sudan with particular reference to the Rhipicephalus sanguineus 
group. Experimental and Applied Acarology, 3(2): 331-346.

Julla II (2003). East Coat fever (Theileria parva infection of cattle) in Southern Sudan. Sudan Journal of Veterinary Science and Animal Husbandry, 42(1): 141-146.

Imam HB (1995). Epidemiological studies of sheep theileriosis in Kassala area. MVSc thesis, Department of parasitology, Faculty of Veterinary Medicine, University of Khartoum, Pp 131.

Karrar G (1987). The consequence of drought, desertification and famine for the population in Eastern and Western country. International Meeting on: Education, skill training and development in the drought stricken areas in Eastern and Western Sudan. Organized by UNESCO, Pp 24-41.

Karrar G Kaiser MN \& Hoogstraal H (1963). Ecology and host-relationships of ticks (Ixodoidea) infesting domestic animals in Kassala Province, Sudan, with special reference to Amblyomma lepidum Dònitz. Bulletin of Entomological Research, 54(3): 509-522.

Latif AA \& Shawgi MH (1982). Calf mortality in Nesheishiba Dairy Farm. In: Proceedings of Pan African Veterinary Congress held in Khartoum Sudan, Pp 170-175.

Latif AA \& Hassan SM (1997). Geographical distribution of ticks in the Sudan using computer models. In: Proceedings of the international workshop on tick modelling held at ICIPE, Nairobi, Kenya. Pp 87-94.

Matthysse JG \& Colbo MH (1987). The ixodid ticks of Uganda. Entomological Society of America, College Park, Maryland. Pp 103105.

Mohamed AS El Malik HH \& Hassan SM (2005). Drop off rhythm and survival periods of Amblyomma lepidum (Acari: Ixodidae) under field conditions. Experimental and Applied Acarology, 36(4): 225-232.

Mohamed EAS (2000). The role of the local people's participation in the development and management of social forestry in the desert prone zone of the Sudan. PhD. thesis, Department of Forestry, Faculty of Agriculture, University of Khartoum, Pp 187.

Mohammed-Ahmed, GM. (2011). Molecular and serological survey of Theileria annulata in North Kordofan State, Sudan. MVM thesis,
Department of parasitology, Faculty of Veterinary Medicine University of Khartoum, Sudan, Pp 84.

Morzaria SP Tatchell R J Minor R Pederson V Julla II Rahim AM Dyson D \& van Aarle PAM (1981). Preliminary studies on the epidemiology of theileriosis in Eastern Equatoria Province of the Sudan. In: Advances in the Control of theileriosis. (MP Cunningham \& AS Young, editors) Martinus, Nijhoff, Pp 83-85.

Nimir AB (2001). Current situation of wildlife in the Sudan. In: A Symposium on Wildlife. 2-3 December 2001, Khartoum, Sudan. (In Arabic). Pp 45-56.

Osman OM (1978). Preliminary notes on the distribution of ticks (Acarina: Ixodidae) in Darfur Province, Sudan. Bulletin of Animal Health and Production in Africa, 24(2):329333.

Osman OM El Hussein AM Ahmed N \& Abdulla HS (1982): Ecological studies on ticks (Acarina, Ixodidae) of Kordofan Region, Sudan. Bulletin of Animal Health and Production in Africa, 30(1): 45-55.

Punyua DK (1985). Longevity of hungry Rhipicephalus appendiculatus Neumann (Acarina: Ixodidae) under field conditions at Muguga, Kenya. Environmentally Entomology, 14(4): 392-395.

Salih DA (2003). Epidemiological studies on tropical theileriosis (Theileria annulata infection of cattle) in the Sudan. MVSc thesis, Department of parasitology, Faculty of Veterinary Medicine, University of Khartoum Pp 103.

Salih DA El Hussein AM Seitzer $U$ \& Ahmed JS (2007). Epidemiological studies on tickborne diseases of cattle in Central Equatoria State, Southern Sudan. Parasitology Research, 101(4): 1035-1044.

Salih DA Hassan SM El Hussein AM \& Jongejan F (2004). Preliminary survey of ticks (Acari: Ixodidae) on cattle in Northern Sudan. Onderstepoort Journal of Veterinary Research, 71(4): 319-326.

Sowar AE (2002). Epidemiology and ecology of ticks and some tick-borne diseases in Kadogli and Dilling Provinces, Southern Kordofan, Sudan. MVSc thesis, Department of parasitology, Faculty of Veterinary Medicine, University of Khartoum, Pp 112. 
Stafford III KC (1994). Survival of immature Ixodes scapularis (Acari: Ixodidae) at different relative humidities. Journal of Medical Entomology, 31(6): 310-314.

Tageldin MH Zakia AM Nagwa EG \& El Sawi SA (1992). An outbreak of Theileriosis in sheep in Sudan. Tropical Animal Health and Production, 24(1): 15-16.

Utech KBW Sutherst RW Dallwitz MJ Wharton RH Maywald GF \& Sutherland, ID (1983). A model of the survival of larvae of cattle tick, Boophilus microplus, on pasture. Austrian Journal of Agricultural Research, 34(1): 63-72.
Walker AR Bouattour A Camicas JL Estrada-Pena A Horak IG Latif AA Pegram RG \& Preston PM (2003). Ticks of domestic animals in Africa: a guide to identification of species. Bioscience Reports, Edinburgh, Pp 145.

Walker JB \& Olwage A (1987). Distribution of Amblyomma variegatum and $A$. hebraeum. Onderstepoort Journal of Veterinary Research, 54(5): 353-379.

Zessin KH \& Baumann MPO (1982). Report on the livestock disease survey, Bahr El Ghazal Province, Sudan. German Agency for Technical Cooperation (GTZ) in cooperation with Federal Health Office, Berlin, Pp 101113. 